\title{
Tissue-Engineered Oral Mucosa Constructs for in Vitro Research and Clinical Applications
}

\author{
Llopis-Grimalt MA ${ }^{1,2 \#}$; Munar-Bestard $\mathbf{M}^{1,2 \#}$, Ramis JM ${ }^{1,2}$ and Monjo $\mathbf{M}^{1,2 *}$ \\ ${ }^{1}$ Group of Cell Therapy and Tissue Engineering, Research Institute on Health Sciences (IUNICS), University of Balearic Islands, Spain \\ ${ }^{2}$ Balearic Islands Health Research Institute (IdISBa), Palma, Spain \\ "both authors equally contributed to this work
}

Received: February 12, 2018; Published: February 19, 2018

*Corresponding author: Marta Monjo Cabrer, Gruop of Cell Therapy and Tissue Engineering, Research Institute of Health Sciences (IUNICS), University of the Balearic Islands, Ctra Valldemossa, Palma, Spain, Tel: 34 971259607; Email: marta.monjo@uib.es

\section{Mini Review}

Monolayer cultures of epithelial or gingival fibroblasts have been used for the study of oral mucosa and the effect of external stimuli, such as different types of dental materials. However, monolayer models lack polarized cell phenotype and systemic components, which affect their function and response to stimuli [1,2]. Several tissue-engineered oral mucosa models have been developed to overcome these limitations with applications in different fields [24]. These 3D cultures provide a higher degree of complexity than monolayer cell cultures being closer to explant cultures, providing an in vitro model resembling the in vivo situation [2]. At least two tissue-engineered oral mucosa models are commercially available, Skin Ethic ${ }^{\mathrm{TM}}$ Oral Epithelium and Gingival Epithelium constructs from EPISKIN (Lyon France), or the Epi Oral ${ }^{\mathrm{TM}}$ and Epi Gingival ${ }^{\mathrm{TM}}$ constructs from Mat Tek Corporation (Ashland, MA, USA). Other commercial skin tissue models are validated to be used as an alternative to animal testing to proof cosmetics safety [5]. Thus, it could be envisaged that in the near future oral tissue models might be approved to test cosmetic dental raw materials or formulations such as tooth pastes or mouthwashes. However, the existing commercial models lack a fibroblast/collagen matrix component, which is critical in human oral mucosa [2].

In order to produce a full thickness tissue-engineered mucosa with epithelial and fibroblasts components, several strategies have been followed using different scaffolds or cells from different origin (Table 1). These differences in scaffold and cell origin are very important depending on the aim of the study or the application of the oral system. In vivo clinical applications include both intraoral graftings (i.e., for use in reconstructions of the oral cavity after tumor resection or the treatment of gingival recession) and extra-oral applications (i.e., for use in urethoplasty, grafting of burn wounds or eyelid reconstruction) [1,6]. For these applications, human primary cells (from the same patient if possible) are used in the fabrication of the oral graft [6]. Besides, in vitro applications include cosmetic testing or study of different dental materials such as titanium implants [7]. These 3D cultures can also be used in oral cancer research to facilitate the study of mechanistic aspects of the disease, early invasion, tumor growth, new treatments or diagnostic tests [8]. For in vitro applications, the use of immortalized cells is preferred, since primary cells are difficult to maintain for a long period of time and results can differ for every cell donor. Buccal carcinoma cell lines may not represent normal epithelial cells; since the results produced using these cells should be interpreted with caution and validated with other cells [2]. Another in vitro application is the use of tissue-engineered oral mucosa as model for the emerging research field that studies soft tissue interaction with dental implant abutments. Human primary oral keratinocytes and human primary oral fibroblasts have been used to produce constructs for this purpose $[9,10]$. In addition, a three-dimensional tissue engineered bone-oral mucosal model has been produced to asses both soft and hard tissue integration on titanium implants [11].

\section{Conclusion}

In conclusion, the use of tissue-engineered oral mucosa constitutes both a therapeutic and a research tool that depending on the given application shall be constructed by a different strategy. 
Table 1: Summary of different strategies (scaffolds and cell types) used to develop tissue-engineered oral mucosa.

\begin{tabular}{|c|c|c|c|}
\hline Scaffold & Cell type & Application & Reference \\
\hline \multicolumn{4}{|l|}{ Acellular dermis } \\
\hline \multirow{2}{*}{ Alloderm $^{\circledast}$ (LifeCell) } & $\begin{array}{l}\text { Primary human keratinocytes and } \\
\text { Immortalized fibroblasts (3T3) }\end{array}$ & $\begin{array}{l}\text { Clinical application for intraoral } \\
\text { grafting procedures }\end{array}$ & {$[12,13]$} \\
\hline & $\begin{array}{l}\text { Primary human oral keratinocytes } \\
\text { and fibroblasts }\end{array}$ & In vitro testing & [10] \\
\hline \multirow[b]{2}{*}{ Deepidermalized dermis } & $\begin{array}{l}\text { Primary canine oral keratinocytes } \\
\text { and Immortalized fibroblasts (3T3) }\end{array}$ & Graft for dog cleft palate repair & [14] \\
\hline & $\begin{array}{l}\text { Keratinocytes derived from human } \\
\text { oral palate }\end{array}$ & $\begin{array}{l}\text { In vitro preparation of bioartificial } \\
\text { mucosa. The authors conclude that } \\
\text { a plate scaffold should be used }\end{array}$ & {$[15]$} \\
\hline \multicolumn{4}{|l|}{ Amniotic membrane } \\
\hline Human amniotic membrane & Primary rabbit oral epithelial cells & $\begin{array}{l}\text { Cornea autologous transplantation } \\
\text { in rabbits }\end{array}$ & [16] \\
\hline \multicolumn{4}{|l|}{ Collagen } \\
\hline \multirow{2}{*}{ Collagen type-I } & $\begin{array}{c}\text { Human oral immortalized } \\
\text { keratinocytes and immortalized } \\
\text { fibroblasts (3T3) }\end{array}$ & In vitro testing & [2] \\
\hline & $\begin{array}{l}\text { immortalized human oral } \\
\text { keratinocytes and primary human } \\
\text { oral fibroblasts }\end{array}$ & In vitro testing & [17] \\
\hline Collagen-chitosan & Primary human oral keratinocytes & In vitro testing & [18] \\
\hline \multirow{2}{*}{ Collagen-elastin } & $\begin{array}{l}\text { Primary human gingival } \\
\text { keratinocytes and primary } \\
\text { fibroblasts }\end{array}$ & $\begin{array}{l}\text { Clinical application in periodontal } \\
\text { therapy }\end{array}$ & [19] \\
\hline & $\begin{array}{l}\text { Primary human palatal mucosa } \\
\text { keratinocytes and primary human } \\
\text { fibroblasts }\end{array}$ & In vitro testing & [20] \\
\hline Collagen-GAG-chitosan & $\begin{array}{l}\text { Primary human palatal mucosa and } \\
\text { primary human fibroblasts }\end{array}$ & In vitro testing & [20] \\
\hline CollaCote ${ }^{\circledast}$ (Zimmer Dental) & $\begin{array}{l}\text { Primary human oral epithelial cells } \\
\text { and human gingival fibroblasts }\end{array}$ & In vitro testing & {$[21]$} \\
\hline \multicolumn{4}{|l|}{ Fibrin } \\
\hline \multirow[b]{2}{*}{ Fibrin matrix } & $\begin{array}{l}\text { Primary human fibroblasts and } \\
\text { keratinocytes from oral mucosa }\end{array}$ & $\begin{array}{l}\text { Clinical application for } \\
\text { ankyloglossia }\end{array}$ & {$[22,23]$} \\
\hline & $\begin{array}{l}\text { Primary human fibroblasts and } \\
\text { keratinocytes from oral mucosa }\end{array}$ & $\begin{array}{c}\text { Clinical application for } \\
\text { hemifacialmicrosomia and } \\
\text { ankyloglossia }\end{array}$ & [24] \\
\hline \multicolumn{4}{|l|}{ Synthetic Scaffolds } \\
\hline Poly (ethylene terephthalate) & \multirow{4}{*}{$\begin{array}{c}\text { Primary human palatal mucosa } \\
\text { keratinocytes and primary human } \\
\text { fibroblasts }\end{array}$} & \multirow{4}{*}{ In vitro Testing } & \multirow{4}{*}[20]{} \\
\hline Polycarbonate membrane & & & \\
\hline Electro-spun poly L-lactic acid & & & \\
\hline Electro-spun polystyrene & & & \\
\hline Polylactic glycolic acid & Primary dog epidermal keratinocytes & $\begin{array}{l}\text { Clinical application for mucosa } \\
\text { prosthesis }\end{array}$ & {$[25]$} \\
\hline
\end{tabular}

\section{Acknowledgement}

This work was supported by the Ministerio de EducaciónCultura y Deporte (contract to M.A.L.G; FPU15/03412), the Instituto de Salud Carlos III (contract to J.M.R; CP 16/00124,) and the Ministerio de Empleo y Seguridad Social with the Sistema de GarantíaJuvenil (contract to M.M.B).

\section{References}

1. Moharamzadeh K (2017) Oral mucosa tissue engineering. Biomater. Oral Dent. Tissue Eng pp. 223-44.

2. Dongari-Bagtzoglou A, Kashleva H (2006) Development of a highly reproducible three-dimensional organotypic model of the oral mucosa. Nat Protoc 1(4): 2012-2018. 
3. Moharamzadeh K, Brook IM, Van Noort R, Scutt AM, Thornhill MH (2007) Tissue-engineered oral mucosa: a review of the scientific literature. J Dent Res 86: 115-124.

4. Buskermolen JK, Reijnders CMA, Spiekstra SW, Steinberg T, Kleverlaan CJ, et al. (2016) Development of a Full Thickness Human Gingiva Equivalent Constructed from Immortalized Keratinocytes and Fibroblasts. Tissue Eng Part C Methods 22: 1-33.

5. de Brugerolle A (2007) SkinEthic Laboratories, a company devoted to develop and produce in vitro alternative methods to animal use. ALTEX 24: 167-171.

6. Liu J, Bian Z, Kuijpers-Jagtman AM, Von Den Hoff JW (2010) Skin and oral mucosa equivalents: Construction and performance. Orthod Craniofacial Res 13: 11-20.

7. Dongari-Bagtzoglou A, Kashleva H (2006) Development of a highly reproducible three-dimensional organotypic model of the oral mucosa. Nat Protoc 1: 2012-2018

8. Colley HE, Hearnden V, Jones A V, Weinreb PH, Violette SM, et al. (2011) Development of tissue-engineered models of oral dysplasia and early invasive oral squamous cell carcinoma. Br J Cancer 105: 1582-1592.

9. Chai WL, Brook IM, Emanuelsson L, Palmquist A, Van Noort R, et al. (2012) Ultrastructural analysis of implant-soft tissue interface on a three dimensional tissue-engineered oral mucosal model. J Biomed Mater Res - Part A 100 A: 269-277.

10. Chai WL, Moharamzadeh K, Brook IM, Emanuelsson L, Palmquist A, et al. (2010) Development of a novel model for the investigation of implantsoft tissue interface. J Periodontol 81: 1187-1195.

11. Almela T, Brook IM, Moharamzadeh K (2016) Development of threedimensional tissue engineered bone-oral mucosal composite models. J Mater Sci Mater Med 27: p65.

12. Izumi K, Feinberg SE, Iida A, Yoshizawa M (2003) Intraoral grafting of an ex vivo produced oral mucosa equivalent: A preliminary report. Int J Oral Maxillofac Surg 32: 188-197.

13. Izumi K, Takacs G, Terashi H, Feinberg SE (1999) Ex vivo development of a composite human oral mucosal equivalent. J Oral Maxillofac Surg 57: 571-577.

14. Ophof R, Rheden REM Van, Hoff JWV Den, Schalkwijk J (2002) Oral keratinocytes cultured on dermal matrices form a mucosa-like tissue 23: $3741-3748$.
15. Cho KH, Ahn HT, Park KC, Chung JH, Kim SW, et al. (2000) Reconstruction of human hard-palate mucosal epithelium on de-epidermized dermis. J Dermatol Sci 22: 117-1124.

16. Nakamura T, Endo KI, Cooper LJ, Fullwood NJ, Tanifuji N, et al. (2003) The successful culture and autologous transplantation of rabbit oral mucosal epithelial cells on amniotic membrane. Investig Ophthalmol Vis Sci 44: 106-116.

17. Almela T, Brook IM, Moharamzadeh K (2016) Development of threedimensional tissue engineered bone-oral mucosal composite models. J Mater Sci Mater Med 27: 1-8.

18. Terada M, Izumi K, Ohnuki H, Saito T, Kato H, et al. (2012) Construction and characterization of a tissue-engineered oral mucosa equivalent based on a chitosan-fish scale collagen composite. J Biomed Mater Res - Part B Appl Biomater 100 B: 1792-1802.

19. Golinski PA, Gröger S, Herrmann JM, Bernd A, Meyle J (2011) Oral mucosa model based on a collagen-elastin matrix. J Periodontal Res 46: 704-711.

20. Moharamzadeh K, Brook IM, Van Noort R, Scutt a M, Smith KG, et al. (2008) Development, optimization and characterization of a fullthickness tissue engineered human oral mucosal model for biological assessment of dental biomaterials. J Mater Sci Mater Med 19: 1793-1801.

21. Rouabhia M, Allaire P (2010) Gingival mucosa regeneration in athymic mice using in vitro engineered human oral mucosa. Biomaterials 31 : 5798-5804.

22. Peña I, Junquera LM, Llorente S, De Villalaín L, De Vicente JC, et al. (2012) Clinical outcomes after the use of complete autologous oral mucosa equivalents: Preliminary cases. Oral Surg Oral Med Oral Pathol Oral Radiol 113: p4-11.

23. Peña I, Junquera LM, Meana Á, García E, García V, et al. (2010) In vitro engineering of complete autologous oral mucosa equivalents: Characterization of a novel scaffold. J Periodontal Res 45: 375-380.

24. Llames S, Recuero I, Romance A, García E, Peña I, et al. (2014) Tissueengineered oral mucosa for mucosal reconstruction in a pediatric patient with hemifacial microsomia and ankyloglossia. Cleft PalateCraniofacial J 51: 246-251.

25. Kim J, Suh SW, Shin JY, Kim JH, Choi YS, et al. (2004) Replacement of a tracheal defect with a tissue-engineered prosthesis: Early results from animal experiments. J Thorac Cardiovasc Surg 128: 124-129.
This work is licensed under Creative Commons Attribution 4.0 License

Submission Link: http://biomedres.us/submit-manuscript.php

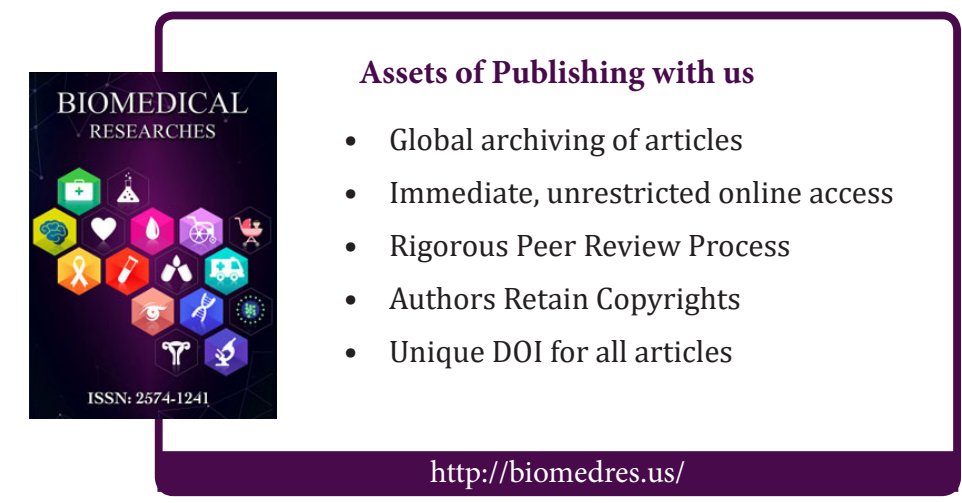

